\title{
Apolipoprotein Al and Transferrin as Biomarkers in Ovarian Cancer Diagnostics
}

\author{
Ronalds Macuks*, Ieva Baidekalna*, Julia Gritcina*, Arina Avdejeva*, Simona Donina**, *** \\ *Riga Stradins University, Riga, Latvia \\ **Latvian Oncology Center, Riga Eastern Clinical University Hospital, Riga, Latvia \\ ***Riga Stradins University, A.Kirhensteins Institute of Microbiology and Virology, Riga, Latvia
}

\begin{abstract}
Summary
Introduction. Advanced technologies such as matrix assisted laser desorption/ionization and surface enhanced laser desorption/ ionization mass spectrometry has introduced promising insights into ovarian cancer detection. Several highly sensitive and specific protein peaks have been identified that discriminates ovarian cancer patients from patients with benign ovarian tumors and controls. Aim of the Study. Objective of this study is to evaluate diagnostic accuracy each individual marker and combined serum biomarker assay consisting of apolipoprotein A1, transferrin and Ca125.

Materials and methods. A case-control study consisted of 99 women - 37 patients with ovarian cancer, 31 patients with benign ovarian diseases, and 31 age-matched healthy controls. Apolipoprotein A1 and transferrin was measured in sera using immunological turbidimetric assay. Tumor marker CA125 was analyzed by standard enzyme-labeled chemiluminescent immunometric assay. To compare the difference between variables in the study groups, ANOVA test was performed and for correlation Pearson's correlation analysis applied. Sensitivity and specificity of the diagnostic tests was calculated using statistical program Vassarstat.

Results. Serum apolipoprotein A1 and transferrin were down regulated, controversially to Ca125, which was up regulated among ovarian cancer patients. Negative correlation between transferrin and $\mathrm{Ca} 125(\mathrm{p}<0.00)$, apolipoprotein $\mathrm{A} 1$ and $\mathrm{Ca} 125(\mathrm{p}<0.00)$ and positive correlation between transferrin and apolipoprotein A1 $(\mathrm{p}<0.00)$ was observed. For single biomarker test highest diagnostic sensitivity and specificity for Ca125 was observed. Addition of apolipoprotein A1 or transferrin to serum level of Ca125 with the condition, that both have to overlap the threshold (Ca125 >21U/ml and apolipoprotein A1 $\leq 139.1 \mathrm{mg} / \mathrm{dl}$ or transferrin $\leq 2.3 \mathrm{~g} / \mathrm{l}$ ), yielded test specificity of $96.7 \%$. Addition of apolipoprotein A1 to Ca125 improved test sensitivity up to $94.5 \%$ maintaining high sensitivity at the same time $91.1 \%$, respectively, when discriminating controls from ovarian cancer patients. Biomarker test consisting of apolipoprotein $\mathrm{A} 1$, transferrin and $\mathrm{Ca} 125$ had high specificity at unacceptable sensitivity.
\end{abstract}

Conclusions. Combined biomarker tests discovered using advanced technologies can aid more accurate ovarian cancer detection. Use of apolipoprotein A1 in combination with Ca125 at distinct thresholds can improve ovarian cancer detection.

Key words: apolipoprotein A1, transferrin, ovarian, cancer; screening.

\section{INTRODUCTION}

Ovarian cancer is the $5^{\text {th }}$ leading cause of death between all cancers and most common between gynecological cancers worldwide. In year 2007-2008 mortality rates in Latvia were 194 and 200 cases each year with an incidence of 309 and 280 cases, respectively.

Cancer antigen 125 is the most studied and well characterized serologic tumor marker for advanced epithelial ovarian cancers. However, its use as a population-based screening tool for early detection and diagnosis of ovarian cancer is limited by its low sensitivity and specificity, therefore a variety of biomarkers have been investigated to improve ovarian cancer detection $(9,12,21)$. Promising results have implemented advanced technologies such as matrix assisted laser desorption/ ionization and surface enhanced laser desorption/ ionization mass spectrometry. Several protein peaks have been identified that discriminates ovarian cancer patients from patients with benign ovarian tumors and controls. Particular technologies already have been used to detect other tumors such as prostate cancer, transitional cell carcinoma of the bladder, and cervical cancer $(1,18,24,25)$.
A comprehensive review of these technologies and clinical applications are described in literature $(4,5,8$, $13,17,26)$.

Several authors have reported about different expression of transferrin and apolipoprotein $\mathrm{Al}$ in serum among ovarian cancer patients and healthy controls improving sensitivity of ovarian cancer diagnostic tests to $74-98 \%$ at specificity of $92-98 \%(3,16,19,27)$.

\section{AIM OF THE STUDY}

Objective of this study is to evaluate diagnostic accuracy of each individual marker and combined serum biomarker assay consisting of apolipoprotein $\mathrm{Al}$, transferrin and Cal25.

\section{MATERIALS AND METHODS}

Ethical approval was taken for this study from the Ethics Committee of Riga Stradins University. A case-control study consisted of 99 women - 37 patients with ovarian cancer in Group A, 31 patients with benign ovarian diseases in Group B, and 31 age-matched healthy controls in Group C. Patients were divided into the 2 study groups after surgery according to final histological 
diagnosis. In Group B were patients thought to have had ovarian cancer before the operation. Patients with severe co-morbidities, previous or coexisting other malignancy were not included in the study. In the both study groups tumors arising only from epithelial origin were included (Table 1).

Table 1. Clinical characteristics and age distribution of 99 study samples

\begin{tabular}{|c|c|c|c|c|c|}
\hline \multirow{2}{*}{$\begin{array}{l}\text { Diagnostic } \\
\text { group }\end{array}$} & \multirow{2}{*}{$\begin{array}{l}\text { Age } \\
\text { range }\end{array}$} & \multirow[b]{2}{*}{$\begin{array}{l}\text { Mean } \\
\text { age }\end{array}$} & \multicolumn{3}{|c|}{ Pathology } \\
\hline & & & Serous & $\begin{array}{c}\text { Endo- } \\
\text { metroid }\end{array}$ & Mucinous \\
\hline Group A & $36-87$ & 60.6 & 35 & 1 & 1 \\
\hline Group B & $40-79$ & 58.0 & 19 & 5 & 7 \\
\hline Group C & $37-81$ & 58.2 & - & - & - \\
\hline
\end{tabular}

Serum samples from patients were collected into two Becton and Dickenson $6 \mathrm{ml}$ serum vaccutainers in the early morning of the planned surgery day. Vaccutainers according to protocol were shaked 6-8 times, left for clot formation between 60 and 120 minutes and centrifuged during the interval for 10 minutes at 1300 RPM. After that serum was aliquoted, divided and transferred into nine $0.5 \mathrm{ml}$ eppendorfs for storage at -80 degrees C. For the control group women serum samples were taken after transvaginal ultrasonographic examination and ensuring of having no gynecological pathology.

In the control group were women chosen who attended gynecologist in out patient clinic.

Tumor marker CAl25 was detected in patient's serum by standard enzyme-labeled chemiluminescent immunometric assay ADVIA Centaur CAl25 II ${ }^{\mathrm{TM}}$, MultiDiluent 1, Bayer, using Siemens analyzer Immulite$2000(1,24)$.

Apolipoprotein Al was measured in sera using immunological turbidimetric assay manufactured by Roche Diagnostics $(2,16,20,22)$.

Transferrin was similarly measured in sera using immunological turbidimetric assay manufactured by Roche Diagnostics $(7,11,23)$. Upper limit of $95 \%$ confidence interval from control group women was chosen as a cutoff level for apolipoprotein Al and transferrin serum concentration.

For ovarian cancer patients a total abdominal hysterectomy with bilateral salpingoophorectomy and omentectomy was performed. Some ovarian cancer patients were subjected for pelvic lymphadenectomy as a staging or cytoreductive procedure. For patients with benign gynecological tumors a total abdominal hysterectomy with or without bilateral salpingoophorectomy was performed.

To evaluate mean biomarker concentrations in the groups, descriptive analysis were performed using statistical program SPSS 17.0. To reflect the standard deviations for the calculated values standard error of the mean was used. To compare the difference between variables in the study groups, ANOVA test was performed and for correlation Pearson's correlation analysis applied. Sensitivity and specificity of the diagnostic tests was calculated using statistical program Vassarstat. To display diagnostic performance of each individual and combined biomarker test, receivers operating curve was drawn.

\section{RESULTS}

Both patient and control groups were similar according to the mean age $(p=0.59)$. Level of Cal25 was analyzed as it is considered as a standard biomarker for ovarian cancer detection.

Serum apolipoprotein Al and transferrin were down regulated in Group A, controversially to Cal25, which was up regulated among ovarian cancer patients (Figure 1)

(a)
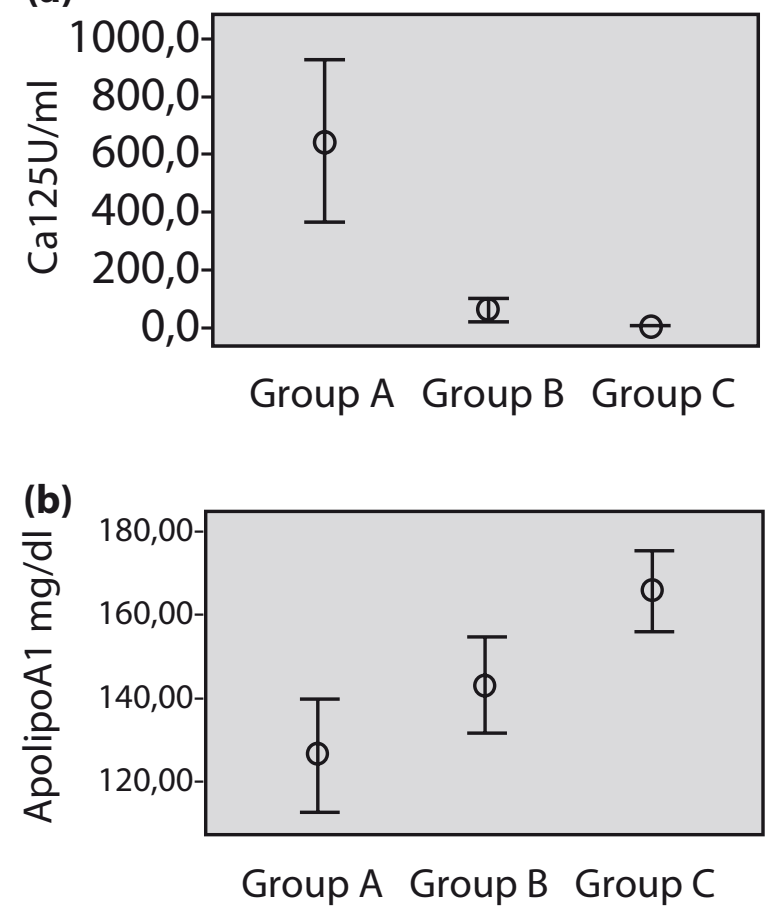

(c)

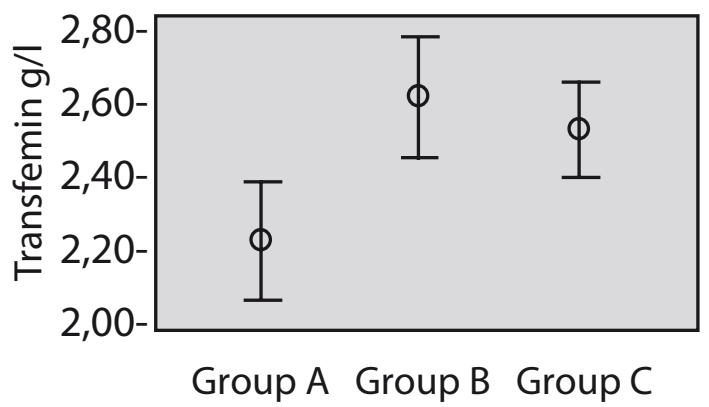

Fig. 1. Distribution of mean serum Cal25 (a), Apolipoprotein Al (b) and Transferrin (c) concentrations among study and control groups 
Difference between mean serum concentrations in the study and control groups were statistically significant, except transferrin concentrations when compared between groups B and C (Tables 2, 3).

Table 2. Mean serum concentrations of serum Transferrin, Apolipoprotein Al and Ca 125 in study and control groups

\begin{tabular}{|c|c|c|c|}
\hline $\begin{array}{c}\text { Diagnostic } \\
\text { group }\end{array}$ & $\begin{array}{c}\text { Transferrin, } \\
\mathrm{g} / \mathrm{l}(95 \% \mathrm{CI})\end{array}$ & $\begin{array}{c}\text { Apolipo Al, } \\
\mathrm{mg} / \mathrm{dl} \\
(95 \% \mathrm{CI})\end{array}$ & $\begin{array}{c}\text { Ca 125, U/ } \\
\mathrm{ml} \\
(95 \% \mathrm{CI})\end{array}$ \\
\hline & & & $627.80 \pm$ \\
Group A & $\begin{array}{c}2.21 \pm 0.08 \\
(2.0-2.3)\end{array}$ & $\begin{array}{c}125.42 \pm 6.75 \\
(111.7-139.1)\end{array}$ & $\begin{array}{c}134.52 \\
(353.7- \\
901.8)\end{array}$ \\
\hline \multirow{2}{*}{ Group B } & $2.61 \pm 0.08$ & $142.36 \pm 30.79$ & $63.70 \pm 17.29$ \\
$(2.4-2.7)$ & $(131-153.6)$ & $(28.3-99.0)$ \\
\hline Group C & $2.52 \pm 0.06$ & $165.35 \pm 26.74$ & $7.37 \pm 0.63$ \\
$(2.4-2.6)$ & $(155.5-175.1)$ & $(6.0-8.6)$ \\
\hline
\end{tabular}

Table 3. Differences among study and control groups mean Transferrin, Apolipoprotein Al and Ca 125 serum concentrations ( $p$ value)

\begin{tabular}{|c|c|c|c|}
\hline $\begin{array}{c}\text { Diagnostic } \\
\text { group }\end{array}$ & Transferrin & Apolipo Al & Ca 125 \\
\hline $\begin{array}{c}\text { Group A } \\
\text { vs. B }\end{array}$ & 0.00 & 0.06 & 0.00 \\
\hline $\begin{array}{c}\text { Group B } \\
\text { vs. C }\end{array}$ & 0.41 & 0.00 & 0.00 \\
\hline $\begin{array}{c}\text { Group C } \\
\text { vs. A }\end{array}$ & 0.00 & 0.00 & 0.00 \\
\hline
\end{tabular}

Negative correlation between transferrin and Ca 125 $(\mathrm{p}<0.00)$, apolipoprotein Al and Ca $125 \quad(\mathrm{p}<0.00)$ and positive correlation between transferrin and apolipoprotein Al $(\mathrm{p}<0.00)$ was observed.

For single biomarker test highest diagnostic sensitivity and specificity for Cal25 was observed. Addition of apolipoprotein Al or transferrin to serum level of Cal25 with the condition, that both have to overlap the threshold $(\mathrm{Cal} 25>21 \mathrm{U} / \mathrm{ml}$ and apolipoprotein Al $\leq 139.1 \mathrm{mg} / \mathrm{dl}$ or transferrin $\leq 2.3 \mathrm{~g} / \mathrm{l})$, improved specificity of the test up to $96.7 \%$. But addition of apolipoprotein Al or Transferrin to serum level of Cal25 with the condition, that one of them have to overlap the threshold, improved test sensitivity up to $94.5 \%$ with decrease in specificity to $59.6 \%-62.9 \%$. Further addition of third biomarker yielded prominent specificity with dramatic decrease in sensitivity (Table 4).
Table 4. Accuracy of individual and combined biomarker diagnostic tests evaluated between Groups A vs. B and C

\begin{tabular}{|c|c|c|}
\hline Biomarkers (threshold) & Sensitivity & Specificity \\
\hline $\begin{array}{c}\text { Apolipoprotein Al } \\
(\leq 139.1 \mathrm{mg} / \mathrm{dl})\end{array}$ & $75.6 \%$ & $70.9 \%$ \\
\hline Transferrin $(\leq 2.3 \mathrm{~g} / \mathrm{l})$ & $72.9 \%$ & $74.1 \%$ \\
\hline Ca $125(>21 \mathrm{U} / \mathrm{ml})$ & $91.9 \%$ & $80.6 \%$ \\
\hline $\begin{array}{c}\text { Apolipoprotein Al } \\
(\leq 139.1 \mathrm{mg} / \mathrm{dl}) \\
\text { and Ca } 125(>21 \mathrm{U} / \mathrm{ml})\end{array}$ & $72.9 \%$ & $88.7 \%$ \\
\hline $\begin{array}{c}\text { Apolipoprotein Al } \\
(\leq 139.1 \mathrm{mg} / \mathrm{dl}) \\
\text { or Ca } 125(>21 \mathrm{U} / \mathrm{ml})\end{array}$ & $94.5 \%$ & $62.9 \%$ \\
\hline $\begin{array}{c}\text { Apolipoprotein Al } \\
(\leq 139.1 \mathrm{mg} / \mathrm{dl}) \text { and } \\
\text { Transferrin }(\leq 2.3 \mathrm{~g} / \mathrm{l}) \\
\end{array}$ & $64.8 \%$ & $93.5 \%$ \\
\hline $\begin{array}{c}\text { Apolipoprotein } \mathrm{Al} \\
(\leq 139.1 \mathrm{mg} / \mathrm{dl}) \text { or } \\
\text { Transferrin }(\leq 2.3 \mathrm{~g} / \mathrm{l})\end{array}$ & $83.7 \%$ & $51.6 \%$ \\
\hline $\begin{array}{c}\text { Transferrin }(\leq 2.3 \mathrm{~g} / \mathrm{l}) \\
\text { and Ca } 125(>21 \mathrm{U} / \mathrm{ml})\end{array}$ & $70.2 \%$ & $96.7 \%$ \\
\hline $\begin{array}{l}\text { Transferrin }(\leq 2.3 \mathrm{~g} / \mathrm{l}) \\
\text { or Ca } 125(>21 \mathrm{U} / \mathrm{ml})\end{array}$ & $94.5 \%$ & $59.6 \%$ \\
\hline $\begin{array}{c}\text { Apolipo Al }(\leq 139.1 \mathrm{mg} / \mathrm{dl}) \\
\text { Transferrin }(\leq 2.3 \mathrm{~g} / \mathrm{l}) \\
\text { and Ca } 125(>21 \mathrm{U} / \mathrm{ml})\end{array}$ & $62.1 \%$ & $100.0 \%$ \\
\hline
\end{tabular}

Similarly, the highest sensitivity and specificity was observed for Cal25 alone when applied to distinguish cancer patients from healthy controls in groups A and C. Only addition of apolipoprotein Al improved test sensitivity up to $94.5 \%$ maintaining high sensitivity at the same time $-91.1 \%$ (Table 5 ). For all other biomarker combinations sensitivity or specificity was low.

Table 5. Accuracy of individual and combined biomarker diagnostic tests evaluated between Groups A and C

\begin{tabular}{|c|c|c|}
\hline Biomarkers (treshold) & Sensitivity & Specificity \\
\hline $\begin{array}{c}\text { Apolipoprotein Al } \\
(\leq 139.1 \mathrm{mg} / \mathrm{dl})\end{array}$ & $75.6 \%$ & $90.3 \%$ \\
\hline Transferrin $(\leq 2.3 \mathrm{~g} / \mathrm{l})$ & $78.3 \%$ & $70.9 \%$ \\
\hline Ca $125(>21 \mathrm{U} / \mathrm{ml})$ & $91.9 \%$ & $100.0 \%$ \\
\hline $\begin{array}{c}\text { Apolipoprotein Al }(\leq 139.1 \mathrm{mg} / \mathrm{dl}) \\
\text { and Ca } 125(>21 \mathrm{U} / \mathrm{ml})\end{array}$ & $72.9 \%$ & $100.0 \%$ \\
\hline $\begin{array}{c}\text { Apolipoprotein Al }(\leq 139.1 \mathrm{mg} / \mathrm{dl}) \\
\text { or Ca } 125(>21 \mathrm{U} / \mathrm{ml})\end{array}$ & $94.5 \%$ & $91.1 \%$ \\
\hline $\begin{array}{c}\text { Apolipoprotein Al } \\
(\leq 139.1 \mathrm{mg} / \mathrm{dl})\end{array}$ & $67.5 \%$ & $100.0 \%$ \\
\hline $\begin{array}{c}\text { Apd Transferrin }(\leq 2.3 \mathrm{~g} / \mathrm{l}) \\
\text { molipoprotein } \mathrm{Al}(\leq 139.1\end{array}$ & $78.3 \%$ & $61.2 \%$ \\
\hline $\begin{array}{c}\text { Transferrin }(\leq 2.3 \mathrm{~g} / \mathrm{l}) \\
\text { and Ca } 125(>21 \mathrm{U} / \mathrm{ml})\end{array}$ & $78.3 \%$ & $100.0 \%$ \\
\hline $\begin{array}{c}\text { Transferrin }(\leq 2.3 \mathrm{~g} / \mathrm{l}) \\
\text { or Ca } 125(>21 \mathrm{U} / \mathrm{ml})\end{array}$ & $94.5 \%$ & $70.9 \%$ \\
\hline
\end{tabular}


Cal25 alone was more accurate predictor of the disease when compared to combinations of Cal25+Apolipoprotein Al or Cal25+Transferrin (Figure 2).

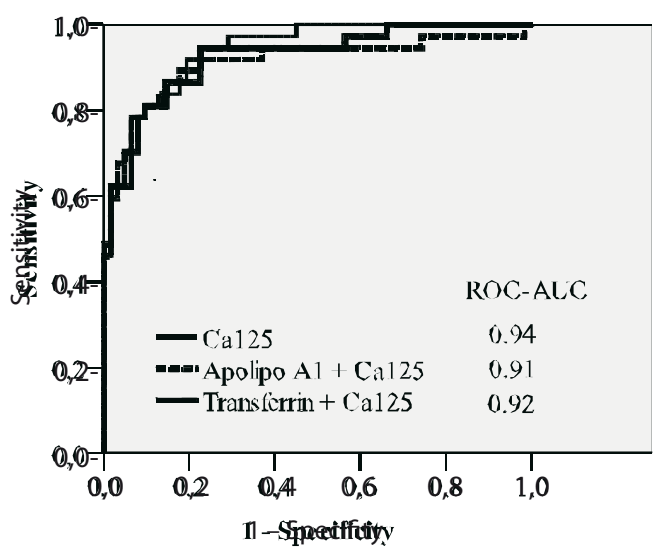

Ca125

Apolipo A1+Ca125

Transferrin + Ca125

Fig. 2. Ability to separate ovarian cancer patients of single and combined biomarker tests

\section{DISCUSSION}

This study reflects facilities of advanced technologies which can separate differently expressed protein levels in ovarian cancer patients and healthy women. Information derived from innovative technologies can aid usage of conventional investigation methods more targeted.

Our sample set contained only 6 patients with early stage ovarian cancers; therefore we were not able to perform comparison of protein expression among early and late stage ovarian cancers.

Despite efforts to find new highly sensitive and specific biomarkers, CA125 still is a most accurate single biomarker for ovarian tumor malignancy prediction. Addition of new biomarkers can only improve diagnostic precision of Cal25.

Numerous studies have noted differently expressed protein peaks of apolipoprotein $\mathrm{Al}$ and transferrin in ovarian cancer and control group patients $(3,6,10,14,28)$. Most of studies had significant improvement in sensitivity and specificity of combined diagnostic tests. In literature there have been published articles about different prediction models, which can discriminate normal serum samples from serum samples derived from patients with low malignancy potential tumors with $91 \%$ sensitivity at specificity of $92 \%$, and normal samples from early stage ovarian cancer with a sensitivity of $89 \%$ at specificity of $92 \%$ (3). Higher diagnostic accuracy of particular study can be explained by having another biomarker transthyretin included in malignancy prediction model. In our study merging of all biomarkers resulted in lower malignancy prediction rates than use of algorithm when apolipoprotein Al should be down regulated or Ca 125 elevated.

Consolidation of all biomarkers offered high specificity with essential decrease of sensitivity. Other authors have reported about high diagnostic sensitivity and specificity reaching $97 \%$ and $99 \%$ (AUC 99\%), respectively, especially combining more than 2 newly discovered serum proteins with Cal25 (3).

\section{CONCLUSIONS}

Combined biomarker tests discovered using advanced technologies can aid more accurate ovarian cancer detection. Use of apolipoprotein Al in combination with Cal 25 at distinct thresholds can improve ovarian cancer detection. Other biomarker incorporation in diagnostic tests should be investigated and further prospective studies with larger sample size are needed to reach clear conclusions.

\section{Conflict of interest: None}

\section{REFERENCES}

1. Banks RE, Dunn MJ, Forbes MA, Stanley A, Pappin D, Naven T, Gough M, Harnden P, Selby PJ. The potential use of laser capture microdissection to selectively obtain distinct populations of cells for proteomic analysis - preliminary findings // Electrophoresis, 1999; 20:689-700

2. Becker W, Rapp W, Schwick HG, Störiko KZ. Methods for the quantitative determination of plasma proteins by immunoprecipitation // Klin Chem Klin Biochem, 1968; 6:1 13-22

3. Feng S, Lang J, Kumar A, Carey N, Hsieh B, Suchard MA., Reddy ST, Farias-Eisner R. Validation of Candidate Serum Ovarian Cancer Biomarkers for Early Detection // Biomarker Insights, 2007; 2:369375

4. Fung ET, Thulasiraman V, Weinberger SR, Dalmasso EA. Protein biochips for differential profiling // (a) Curr Opin Biotechnol, 2001;12:65-69

5. Fung ET, Wright GL Jr, Dalmasso EA. Proteomic strategies for biomarker identification: progress and challenges // (b) Curr Opin Mol Ther, 2000; 2:643-650

6. Goufman EI, Moshkovskii SA, Tikhonova OV, Lokhov PG, Zgoda VG, Serebryakova MV, Toropygin IY, Vlasova MA, Safarova MR, Makarov OV, Archakov AI. Two-dimensional electrophoretic proteome study of serum thermostable fraction from patients with various tumor conditions // Biochemistry (Mosc), 2006; $71(4): 354-60$

7. Heidelberg M, Kendall FE // J Exp Med, 1935; 62:697

8. Hood BL, Malehorn DE, Conrads TP, Bigbee WL. Serum proteomics using mass spectrometry // Methods Mol Biol, 2009; 520:107-28

9. Jacobs I, Bast RC Jr. The CA 125 tumour-associated antigen: a review of the literature // Hum Reprod, 1989; 4:1-12 
10. Kozak KR, Su F, Whitelegge JP, Faull K, Reddy S, Farias-Eisner R. Characterization of serum biomarkers for detection of early stage ovarian cancer // Proteomics, 2005; 5(17):4589-96

11. Lizana J, Hellsing K. Manual immunoephelometric assay of proteins, with use of polymer enhancement // Clin Chem, 1974; 20:1181-6

12. MacDonald ND, Jacobs IJ. Is there a place for screening in ovarian cancer // Eur J Obstet Gynecol Reprod Biol, 1999; 82:155-157

13. Merchant $M$, Weinberger SR. Recent advancements in surface-enhanced laser desorption/ionization time-of-flight mass spectrometry // Electrophoresis, 2000; 21:1164-1177

14. Moore LE, Fung ET, McGuire $M$, Rabkin CC, Molinaro A, Wang Z, Zhang F, Wang J, Yip C, Meng XY, Pfeiffer RM. Evaluation of apolipoprotein $\mathrm{Al}$ and posttranslationally modified forms of transthyretin as biomarkers for ovarian cancer detection in an independent study population // Cancer Epidemiol Biomarkers Prev, 2006; 15(9):1641-6

15. Naito HK. Reliability of lipid, lipoprotein, and apolipoprotein measurements // Clin Chem, 1988; 34:84-94

16. Nosov V, Su F, Amneus M, Birrer M, Robins T, Kotlerman J, Reddy S, Farias-Eisner R. Validation of serum biomarkers for detection of early-stage ovarian cancer // Am J Obstet Gynecol, 2009; 200:639

17. Palmer-Toy D, Kuzdzal S, Chan, DW. Proteomic approaches to tumor marker discovery // In: Diamandis EP, Fritsche H, Lilja H, Chan DW, Schwartz M, eds. Tumor Markers Physiology, Pathobiology, Technology and Clinical Applications. Philadelphia: AACC Press; 2002; 391-400

18. Paweletz CP, Gillespie JW, Ornstein DK, Simone NL, Brown MR, Cole KA, Wang QH, Huang J, Hu N, Yip TT, Rich WE, Kohn EC, Linehan WM, Weber T, Taylor P, Emmert-Buck MR, Liotta LA, Petricoin EF. Rapid protein display profiling of cancer progression directly from human tissue using a protein biochip // Drug Dev Res, 2000; 49:34-42

19. Rai AJ, Zhang Z, Rosenzweig J, Shih I, Pham T, Fung ET, Sokoll LJ, Chan DW. Proteomic Approaches to Tumor Marker Discovery Identification of Biomarkers for Ovarian Cancer // Arch Pathol Lab Med, 2002; 126(12):1518-1526

20. Rifai N, King ME. Immunoturbidimetric assays of apolipoproteins A, AI, AII, and B in serum // Clin Chem, 1986; 32:957-61
21. Shih IM, Sokoll LJ, Chan DW. Tumor markers in ovarian cancer // In: Diamandis EP, Fritsche $H$, Lilja H, Chan DW, Schwartz M. Tumor Markers Physiology, Pathobiology, Technology and Clinical Applications. Philadelphia: AACC Press; 2002; 239-252Siedel J, Schiefer S, Rosseneu M, Bergeaud R, De Keersgieter W, Pautz B, Vinaimont N, Ziegenhorn J. Immunoturbidimetric method for routine determinations of apolipoproteins A-I, A-II, and B in normo- and hyperlipemic sera compared with immunonephelometry // Clin Chem, 1988; 34:1821-5

22. Tietz NW. Transferrin // In: Tietz NW. Fundamentals of clinical Chemistry. 2nd ed. Philadelphia: WB Saunders; 1976; 278-280

23. Vlahou A, Schellhammer PF, Mendrinos S, Patel K, Kondylis FI, Gong L, Nasim S, Wright Jr. Development of a novel proteomic approach for the detection of transitional cell carcinoma of the bladder in urine // Am J Pathol, 2001; 158:14911502

24. Von Eggeling F, Junker K, Fiedler W, Wollscheid V, Dürst M, Claussen U, Ernst G. Mass spectrometry meets chip technology: a new proteomic tool in cancer research // Electrophoresis, 2001; 22: 28982902

25. Weinberger SR, Morris TS, Pawlak M. Recent trends in protein biochip technology // Pharmacogenomics, 2000; 1:395-416

26. Zhang Z, Bast RC, Jr, Yu Y, Li J, Sokoll LJ, Rai AJ, Rosenzweig JM, Cameron B, Wang YY, Meng XY, Berchuck A, Van Haaften-Day C, Hacker NF, de Bruijn HWA, Van der Zee AGJ, Jacobs IJ, Fung ET, Chan DW. Three Biomarkers Identified from Serum Proteomic Analysis for the Detection of Early Stage Ovarian Cancer // Cancer Research, 2004; 64:5882-5890

27. Zhao Q, Duan W, Wu YM, Qian XH, Deng XH. Analysis of serum biomarkers of ovarian epithelial cancers based on 2-DE DIGE and MALDI TOF/TOF // Zhonghua Zhong Liu Za Zhi, 2008; 30(10):754-8

\section{Acknowledgement}

Studywasdonewithin theframework ofLatvianUniversity project (number: 2009/0220/1DP/1.1.1.2.0/09/APIA/ VIAA/016) and P.Stradins University project (number: 2009/0147/1DP/1.1.2.1.2/09/IPIA/VIAA/009)".

\author{
Address: \\ Ronalds Macuks \\ Mezciema street 23/1-55, \\ Riga, Latvia, LV-1079 \\ E-mail: r.macuks@gmail.com
}

